\title{
Utilization of Lime Mud Waste from Paper Mills for Efficient Phosphorus Removal
}

\author{
Hong Ha Thi Vu ${ }^{1}$, Mohd Danish Khan ${ }^{2}$, Ramakrishna Chilakala ${ }^{3}$, Tuan Quang Lai ${ }^{2}$, \\ Thriveni Thenepalli ${ }^{1}{ }^{\mathbb{D}}$, Ji Whan Ahn ${ }^{1}$, Dong Un Park ${ }^{4}$ and Jeongyun Kim ${ }^{1, *}$ \\ 1 Center for Carbon Mineralization, Mineral Resources Division, Korea Institute of Geoscience and Mineral \\ Resources, 124 Gwahak-ro, Gajeong-dong, Yuseong-gu, Daejeon 34132, Korea; \\ hongha@kigam.re.kr (H.H.T.V.); thenepallit@rediffmail.com (T.T.); ahnjw@kigam.re.kr (J.W.A.) \\ 2 Resources Recycling Department, University of Science and Technology, 217, Gajeong-ro, Yuseong-gu, \\ Daejeon 34113, Korea; danish0417@ust.ac.kr (M.D.K.); tuanlai@ust.ac.kr (T.Q.L.) \\ 3 Department of Bio-Based Materials, School of Agriculture and Life Science, Chungnam National University \\ Daejeon-34132, Korea; chilakala_ramakrishna@rediffmail.com \\ 4 Center for Climate Technology Cooperation, 17th Floor, Namsan Square Bldg., 173, Toegye-ro, Jung-gu, \\ Seoul 04554, Korea; dongun.park@gtck.re.kr \\ * Correspondence: kooltz77@kigam.re.kr
}

Received: 8 February 2019; Accepted: 9 March 2019; Published: 13 March 2019

check for updates

\begin{abstract}
In this study, we utilized lime mud waste from paper mills to synthesize calcium hydroxide $\left(\mathrm{Ca}(\mathrm{OH})_{2}\right)$ nanoparticles (NPs) and investigate their application for the removal of phosphorus from aqueous solution. The NPs, composed of green portlandite with hexagonal shape, were successfully produced using a precipitation method at moderately high temperature. The crystal structure and characterization of the prepared $\mathrm{Ca}(\mathrm{OH})_{2}$ nanoparticles were analyzed by field emission scanning electron microscopy, Fourier transform infrared spectroscopy, and X-ray diffraction. The effects of $\mathrm{Ca}(\mathrm{OH})_{2} \mathrm{NP}$ dosage and contact time on removal of phosphorus were also investigated. The results show that the green portlandite NPs can effectively remove phosphorus from aqueous solution. The phosphorus removal efficiencies within $10 \mathrm{~min}$ are 53\%,72\%, 78\%, 98\%, and 100\% with the different mass ratios of $\mathrm{Ca}(\mathrm{OH})_{2} \mathrm{NPs}$ / phosphorus (CNPs/P) of 2.2, 3.5, 4.4, 5.3, and 6.2, respectively. Due to the efficient phosphorus removal, the calcium hydroxide nanoparticles (CNPs) could be a potential candidate for this application in domestic or industrial wastewater treatment.
\end{abstract}

Keywords: calcium hydroxide; lime mud; nanoparticles; phosphorus removal

\section{Introduction}

Pulp and paper industries are producing an enormous amount of pulp annually to meet the ever-growing demand for papers and packaging materials [1-3]. Statistics also revealed that the global paper and cardboard production rose from 391.2 to 410.9 million metric tons from the year 2008 to 2016 [4]. Countries such as China, the United States, and Japan account for more than 50\% of total paper and cardboard production. China alone produces more than 111.3 million metric tons (as of 2016) and currently is the largest producer of pulp and cardboard, followed by the United States, Japan, and South Korea [5]. However, organic and inorganic wastes (dregs and ash) are produced in huge quantities as byproducts, causing severe ecological and environmental issues. Lime mud is one such byproduct and its estimated outcome accounts for approximately $0.47 \mathrm{~m}^{3}$ tons $\mathrm{s}^{-1}$ of pulp produced [6]. Lime mud is produced during the wood chips-to-pulp conversion process for paper production. The pulp is extracted from those wood chips through sodium hydroxide treatment and sodium carbonate is formed as a byproduct. For the recovery of sodium hydroxide, calcium oxide (quicklime) is then added to sodium carbonate slurry and calcium carbonate is formed, which is 
termed as 'lime mud'. Trace amounts of other elements such as magnesium, potassium, sulfur, and boron can also be found in lime mud.

Lime mud is classified as a toxic industrial waste mainly due to its high alkalinity and typical mineralogical characteristics and therefore requires proper treatment before discharge [7]. Reutilization of lime mud is very limited in industries and accounts for only $30 \%$ of lime mud produced, while the remainder is disposed of in landfills. However, many serious environmental issues are associated with disposal in landfills: (a) large landfill area occupation with high disposal cost; (b) landfill leachates moving into groundwater and rivers; (c) adverse impacts on nearby plants and soils; (d) toxic fine dust generation in dry and windy conditions [8]. Furthermore, landfills are also suggested to be an unsuitable option for lime mud disposal [9]. Therefore, there is an utmost requirement for cost-effective reutilization and valorization of lime mud.

Lime mud is used in many applications, such as building materials (bricks and cements) [10], wastewater treatment [11], and agricultural soils [12]. However, high costs involved in pretreatment processes such as drying, desalting, or dewatering makes lime mud a secondary option. Therefore, lime mud valorization can be a possible option to yield a more value-added product. Lime mud is mostly composed of calcium carbonate ( 95-96\%), and with a few steps of pretreatment, it can be converted into calcium carbonate $\left(\mathrm{CaCO}_{3}\right)$, calcium oxide $(\mathrm{CaO})$, calcium hydroxide $\left(\mathrm{Ca}(\mathrm{OH})_{2}\right)$, ceramsite, and bioceramics [13-15]. This valorization can produce $\mathrm{CaO}$ and $\mathrm{Ca}(\mathrm{OH})_{2}$, which has the capacity to effectively remove phosphate. The nanoscale size of produced product provides enormous surface area and activated surface for effective adsorption of phosphorus, fluoride, and many other heavy metals such as $\mathrm{Pb}, \mathrm{Cu}, \mathrm{As}$, and $\mathrm{Cd}$ [16-18]. Numerous studies have been performed on bioceramics, lime sludge, and red mud ( $46 \mathrm{wt}$. \% of $\mathrm{CaO}$ ), which have similar compositions to lime mud, for the removal of phosphorus through surface adsorption and wet chemical precipitation processes [13,19-21], whereas utilization of lime mud for phosphorus removal has not yet been documented, to the best of our knowledge.

Phosphorus is a very important element for the industries of fertilizers [22], pharmaceuticals [23], detergents [24], and batteries [25]. These industries inevitably discharge a significant amount of phosphorus-bearing wastes (mostly in the form of phosphates) in effluent streams, which ultimately causes serious environmental issues. Phosphorus is the key element responsible for the occurrence of eutrophication as it encourages the growth of algae [26,27], which then adversely affects the overall aquatic life. Severe oxygen depletion due to higher eutrophication and biological oxygen demands are some of the major consequences [28]. This directly affects the water quality and hampers aquatic life. Therefore, removal and recovery of this useful element is highly desirable to minimize any environmental impact, particularly in nearby regions of urban areas.

Conventional phosphorus treatment methods include adsorption, biological treatments, precipitation, floatation, and crystallization [29]. The reduced removal efficiencies and complex operations make most of the mentioned methods unsuitable for commercial purposes. Chemical precipitation technique is widely accepted and is also capable of removing more than $99 \%$ of phosphorus from wastewater. Moreover, precipitation of phosphorus in the form of calcium phosphate is an important physicochemical process. This further promotes the efficient and economical route for the recovery of phosphorus [28].

Numerous studies have already been conducted on the treatment of phosphorus from various chemicals in wastewater through the precipitation method [28-33]. Among them, calcium-based compounds were very effective and could even reach up to $99 \%$ phosphorus removal efficiency [32]. In particular, calcium hydroxide has some merits over other metal salts, including that it does not induce metal ions such as $\mathrm{Al}^{3+}$ or $\mathrm{Fe}^{3+}$ and anions such as $\mathrm{SO}_{4}{ }^{2-}$ or $\mathrm{Cl}^{-}$in the treated water. In the present work, an attempt has been made to develop green nano-calcium hydroxide from lime mud without using any toxic chemicals or energy-intensive processes. 
The objectives of the present work are to valorize lime mud into a value-added product, i.e., green nano-calcium hydroxide, and to determine the optimum dosage of green nano-calcium hydroxide and residence time required for the maximum removal of phosphorus from wastewater.

\section{Materials and Methods}

\subsection{Green $\mathrm{Ca}(\mathrm{OH})_{2}$ Preparation}

Lime mud was collected from the Moorim paper mill in Ulsan, Republic of Korea. The composition of raw lime mud was predominantly calcium carbonate with small amounts of other oxides containing $\mathrm{Al}_{2} \mathrm{O}_{3}, \mathrm{SiO}_{2}, \mathrm{SO}_{3}, \mathrm{P}_{2} \mathrm{O}_{5}, \mathrm{Na}_{2} \mathrm{O}, \mathrm{Fe}_{2} \mathrm{O}_{3}$, and $\mathrm{MgO}$. Hydrochloric acid ( $\mathrm{HCl}, 35-37 \%$ concentration) and sodium hydroxide ( $\mathrm{NaOH}, 97 \%$ purity) were purchased from Junsei Chemicals, Republic of Korea. All chemicals were used as received.

The green $\mathrm{Ca}(\mathrm{OH})_{2}$ nanoparticles were prepared by a precipitation method involving the following chemical reaction:

$$
\begin{gathered}
\mathrm{CaCO}_{3 \text { (solid) }} \text { (lime mud) }+2 \mathrm{HCl}_{\text {(aqueous) }} \rightarrow \mathrm{CaCl}_{2 \text { (aqueous) }}+\mathrm{CO}_{2 \text { (gas) }}+\mathrm{H}_{2} \mathrm{O}_{\text {(aqueous) }} \\
\mathrm{CaCl}_{2 \text { (aqueous) }}+2 \mathrm{NaOH}_{\text {(aqueous) }} \rightarrow \mathrm{Ca}(\mathrm{OH})_{2 \text { (solid) }}+2 \mathrm{NaCl}_{\text {(aqueous) }}
\end{gathered}
$$

Firstly, the lime mud was ground and screened through a sieve of $100 \mu \mathrm{m}$. Then, $12.5 \mathrm{~g}$ of fine powder lime mud was dissolved in $250 \mathrm{~mL}$ of $1 \mathrm{M} \mathrm{HCl}$ under vigorous stirring. In order to remove residues, the solution was filtered to $0.45 \mu \mathrm{m}$ particle size by paper filter and syringe filter. After filtering, a transparent solution was obtained. Then, the transparent solution was heated at $90^{\circ} \mathrm{C}$ due to the minimum solubility of $\mathrm{CO}_{2}$ in water. Moreover, the calcium hydroxide nanoparticles (CNPs) should have a perfect shape if the temperature is around $90^{\circ} \mathrm{C}[34,35]$. When the temperature of the transparent solution reached $90^{\circ} \mathrm{C}, 200 \mathrm{~mL}$ of $1 \mathrm{M} \mathrm{NaOH}$ solution was added dropwise into the resultant solution under vigorous magnetic stirring while keeping the temperature of the mixed solution around $90^{\circ} \mathrm{C}$. Subsequently, the transparent mixture became white in color within $5 \mathrm{~min}$. Finally, the white solution was filtered, and then the residue was washed by deionized water several times to remove remaining impurities and dried in an oven at $100{ }^{\circ} \mathrm{C}$ for one day.

\subsection{Phosphorus Removal Study}

The potassium dihydrogen phosphate $\left(\mathrm{KH}_{2} \mathrm{PO}_{4}\right)$ (extra pure reagent, Daejung Chemicals \& Metal Co., Ltd, Korea) was dissolved in DI water to prepare $15 \mathrm{mg} \mathrm{L}^{-1}$ phosphorus solution. Different mass ratios of $\mathrm{Ca}(\mathrm{OH})_{2} \mathrm{NPs} /$ phosphorus $(\mathrm{CNPs} / \mathrm{P})(2.2,3.5,4.4,5.3,6.2)$ were added into different beakers containing $150 \mathrm{~mL}$ of phosphorus solution with fixed concentration of $15 \mathrm{mg} \mathrm{L}^{-1}(\mathrm{pH} 7)$ under $300 \mathrm{rpm}$ magnetic stirring at room temperature and with difference contact times of 1,5, 10, 20, and $60 \mathrm{~min}$. A slight change in $\mathrm{pH}(\sim 0.5)$ was observed upon addition of CNPs. The solution in the treatment beaker was directly filtered through a $0.45 \mu \mathrm{m}$ syringe filter to separate the nanoparticles from the phosphorus solution. The filtrate was then analyzed for remaining concentration of phosphorus in the solution by a spectrophotometer (HS 3300, HUMAS) using the ascorbic acid method (3000 TP-L program). The phosphorus removal efficiency $\mathrm{E} \%$ was determined using the following equation:

$$
\mathrm{E} \%=\frac{C_{0}-C}{C_{0}} \times 100
$$

where $C_{0}$ is the primary concentration of total phosphorus $\left(\mathrm{mg} \mathrm{L}^{-1}\right)$ and $C$ is the concentration of total phosphorus after treatment $\left(\mathrm{mg} \mathrm{L}^{-1}\right)$.

\subsection{Physical Characterization}

The crystal structure study and the identification for mineral phases of lime mud waste and the prepared $\mathrm{Ca}(\mathrm{OH})_{2}$ sample were examined by X-ray diffraction (XRD; BD2745N) with an X-ray 
source of $\mathrm{Cu} \mathrm{K} \alpha(\lambda=0.15406 \mathrm{~nm})$ in the scan range of diffraction angle $2 \theta$ from $20^{\circ}$ to $80^{\circ}$. In order to identify characteristic functional groups and structure properties, the samples were measured by Fourier transform infrared spectroscopy (FT-IR; 6700 FTIR) with the scan range from 400 to $4000 \mathrm{~cm}^{-1}$. The samples were directly analyzed by FT-IR without any further sample preparation. The morphological features of lime mud sample were investigated by scanning electron microscopy (SEM; JSM-6380). The $\mathrm{Ca}(\mathrm{OH})_{2}$ NPs micro images were recorded by field emission scanning electron microscopy (FE-SEM; Hitachi-S-4800) to find out the morphologies and size of CNPs.

For analysis concentration of phosphorus before and after treatment, the solutions were measured by the water analyzer and spectrophotometer (HUMAS, HS-3300) at $880 \mathrm{~nm}$ using the ascorbic acid colorimetric method.

\section{Results}

\subsection{Characteristics of Green $\mathrm{Ca}(\mathrm{OH})_{2}$}

Regarding the characterization of crystal structure of the raw lime mud and CNPs, the samples were examined by $\mathrm{XRD}$, as shown in Figure 1. The raw lime mud (black line) is highly crystalline. The resultant peaks are in good agreement with the mineralogical phase of rhombohedral calcite $\left(\mathrm{CaCO}_{3}\right)$, having space group R-3c (space group No. 167. PDF card No. 00_081_2027). The XRD peaks at $2 \theta=23.1^{\circ}, 29.3^{\circ}, 35.9^{\circ}, 39.4^{\circ}, 43.1^{\circ}, 47.1^{\circ}, 47.5^{\circ}, 48.4^{\circ}, 56.5^{\circ}, 57.3^{\circ}, 60.6^{\circ}$, and $64.6^{\circ}$ were assigned to the (012), (104), (110), (113), (202), (024), (018), (116), (211), (122), (214), and (300) planes of the calcite phase, respectively. For $\mathrm{Ca}(\mathrm{OH})_{2}$ nanoparticles (red line), the major diffraction peaks matched very well with the characteristic peaks of the hexagonal portlandite phase of space group P-3m1 (Space Group No. 164, PDF Card No. 00-087-0673) [34]. The peaks at $2 \theta=28.6^{\circ}, 34.0^{\circ}, 47.0^{\circ}, 50.6^{\circ}, 54.2^{\circ}$, $62.5^{\circ}, 64.1^{\circ}$, and $71.7^{\circ}$ corresponded to the (100), (101), (102), (110), (111), (021), (013), and (002) planes of the portlandite phase, respectively. Besides, a minor calcite peak was found at $2 \theta=29.3^{\circ}$ due to reaction of portlandite and carbon dioxide from air. Moreover, the crystallite size $(\mathrm{d})$ of produced $\mathrm{Ca}(\mathrm{OH})_{2} \mathrm{NP}$ powder was calculated based on the Debye-Scherrer's equation:

$$
d=\frac{K \lambda}{\beta \cos \theta}
$$

where $K$ is Debye-Scherrer's constant, equal to 0.090, $\lambda$ is the wavelength of $X$-ray radiation used $(\lambda=0.15406 \mathrm{~nm}), \theta$ is the Bragg diffraction angle, and $\beta$ is the half-width diffraction peak. The estimated mean crystal size of portlandite NPs for the plane (101) (with the highest diffraction peak) was approximately $24.8 \mathrm{~nm}$. The lattice strain $\varepsilon$ of crystal at the plane was calculated with the following equation:

$$
\varepsilon=\frac{\beta}{4 \tan \theta}
$$

The lattice strain was found to be $4.775 \times 10^{-3}$ for the plane (101) [36-38].

To observe the structural transformation from lime mud to portlandite nanoparticles, SEM and Field Emission Scanning Electron Microscopy (FESEM) analyses were conducted. Figure 2a,b shows the scanning electron microscope images of a lime mud sample. The micrograph shows that the lime mud has irregular shape and agglomerate units. The size range of lime mud is from $300 \mathrm{~nm}$ to $10 \mu \mathrm{m}$. After preparation, the $\mathrm{Ca}(\mathrm{OH})_{2} \mathrm{NP}$ structure revealed irregular shape to hexagonal shape features with varying sizes, as shown in Figure 2c. Figure $2 \mathrm{~d}$ clearly shows the hexagonal nanoplate of $\mathrm{Ca}(\mathrm{OH})_{2}$ nanoparticles with size of approximately $550-700 \mathrm{~nm}$. Furthermore, the impurity in the form of calcite in the prepared $\mathrm{Ca}(\mathrm{OH})_{2}$ nanoparticles sample was also observed through the FESEM image. The calcite $\mathrm{CaCO}_{3}$ revealed a nano-fibrous shape and nano-needle shape (Figure 2c). Other studies also verified the formation of nano-portlandite with similar morphologies and size. Darroudi et al. reported the preparation of calcium hydroxide nanoparticles with hexagonal structure and average particle size range of $600-650 \mathrm{~nm}$ by a facile sol-gel method in aqueous gelatin media [39]. Pereira et al. 
introduced $\mathrm{Ca}(\mathrm{OH})_{2}$ nanoplates with average dimensions of $100-300 \mathrm{~nm}$ and hexagonal shape [40]. Madrid et al. produced high-purity hexagonal nano-calcium hydroxide with 200-600 nm size by a precipitation method in $\mathrm{N}_{2}$ atmosphere and at different temperatures [35]. $\mathrm{Ca}(\mathrm{OH})_{2}$ nanoplates of size ranging from $350 \mathrm{~nm}$ to $450 \mathrm{~nm}$ were also developed from waste oyster shells by Khan et al. [34].

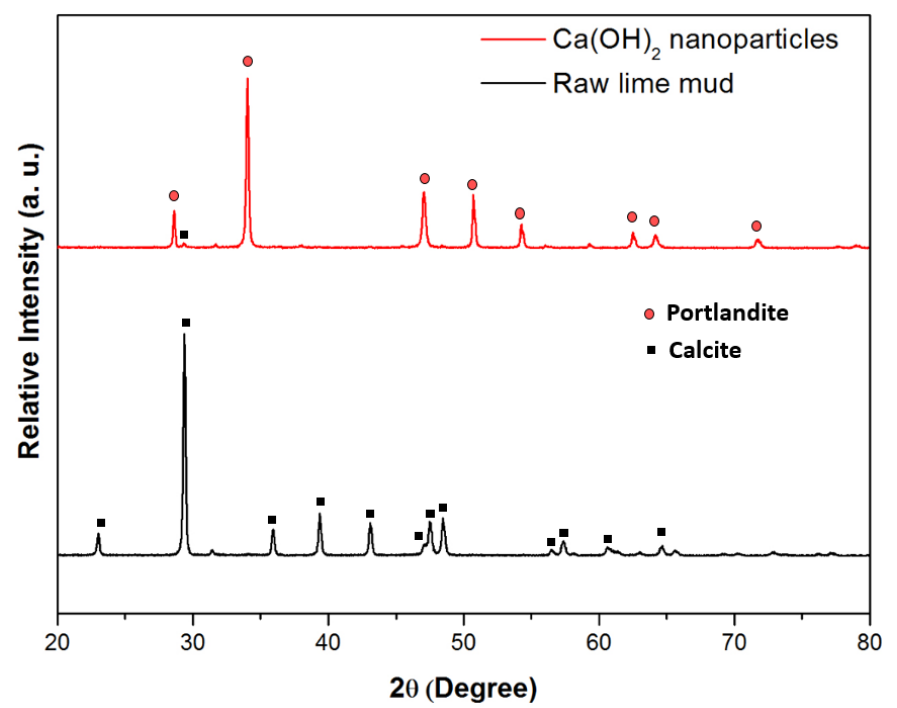

Figure 1. The XRD patterns of raw lime mud (black line) and $\mathrm{Ca}(\mathrm{OH})_{2}$ nanoparticles (red line).

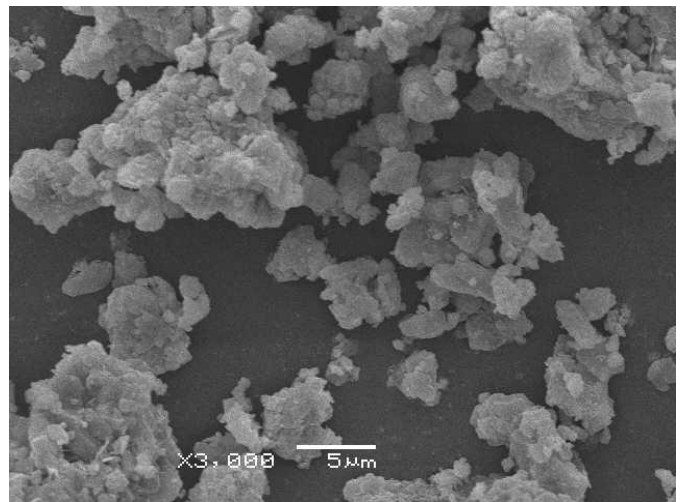

(a)

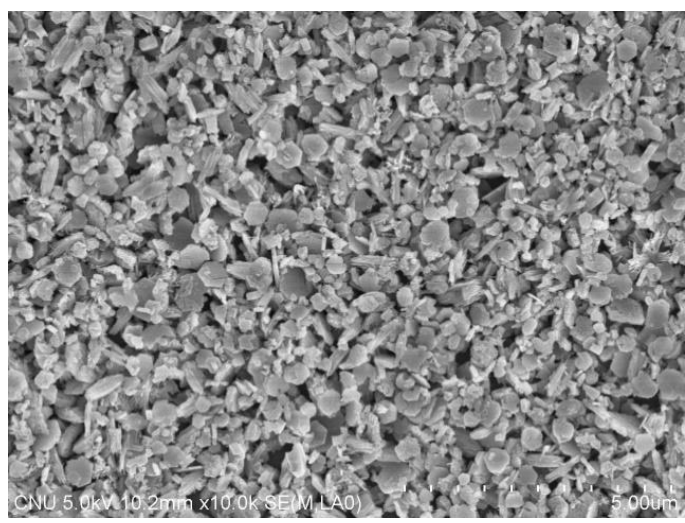

(c)

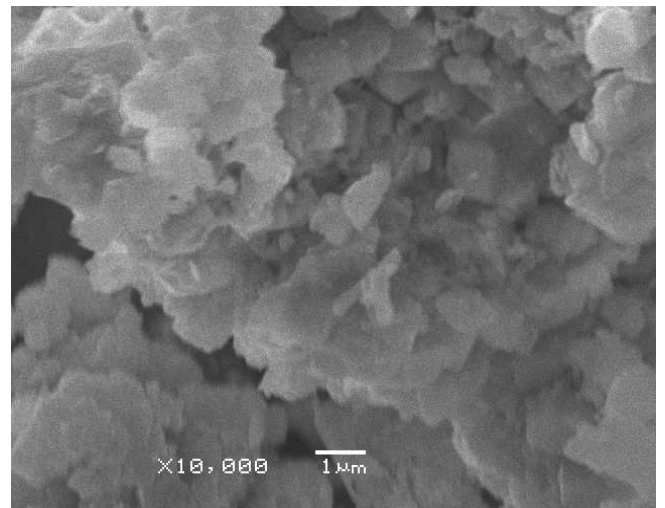

(b)

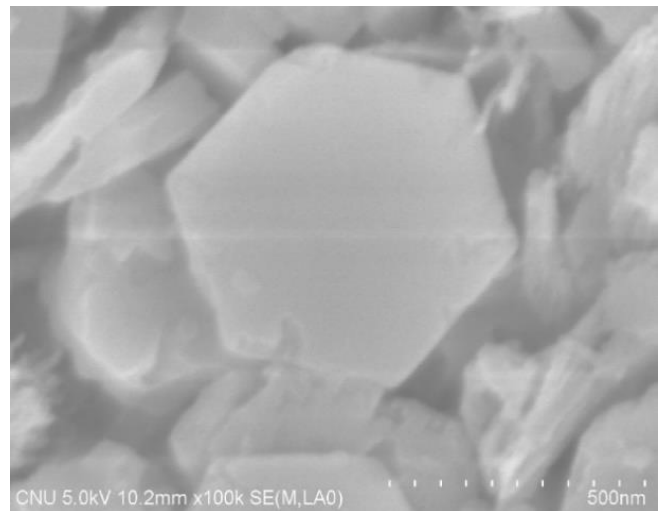

(d)

Figure 2. SEM analysis of lime mud samples and FESEM analysis of calcium hydroxide nano particles. (a) Low- and (b) high-magnification SEM images of raw lime mud; (c) low- and (d) high-magnification Field Emission Scanning Electron Microscopy (FESEM) of $\mathrm{Ca}(\mathrm{OH})_{2}$ nanoparticles. 
To identify the characteristic functional groups, the FTIR spectra of samples were recorded. Figure 3 presents the FTIR patterns of (a) raw lime mud and (b) $\mathrm{Ca}(\mathrm{OH})_{2}$ nanoparticles. The FTIR spectra of raw lime mud indicated that the major composition of lime mud is calcite, as shown in Figure 3a. The broad stretching absorption and sharp peaks at 712, 871, and $1426 \mathrm{~cm}^{-1}$ denote $v_{4}$ (in-plane bending mode), $v_{2}$ (out-of-plane bending mode), and $v_{3}$ (antisymmetric stretching mode) of the $\mathrm{CO}_{3}{ }^{2-}$ group of the calcite [41]. For green portlandite, the absorption peak at $3641.7 \mathrm{~cm}^{-1}$ was assigned to the characteristic hydroxyl group $\left(\mathrm{OH}^{-}\right)$stretching vibration in the portlandite phase, as shown in Figure $3 b$ [42]. Furthermore, the weak absorption bands at $871 \mathrm{~cm}^{-1}\left(v_{2}\right)$ and $1426 \mathrm{~cm}^{-1}$ $\left(v_{3}\right)$ correspond to the stretching of the carbonate $\left(\mathrm{CO}_{3}{ }^{2-}\right)$ group of the calcite phase, which was also confirmed in XRD result.

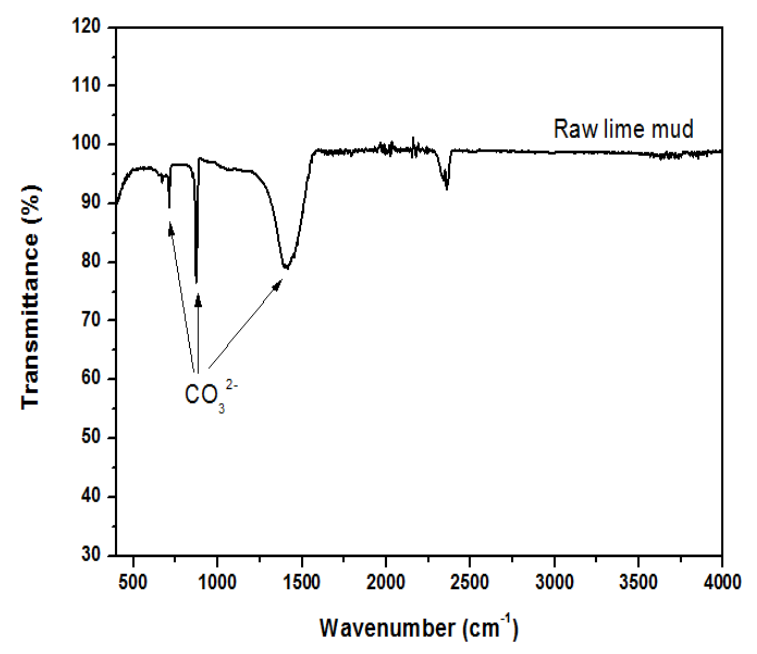

(a)

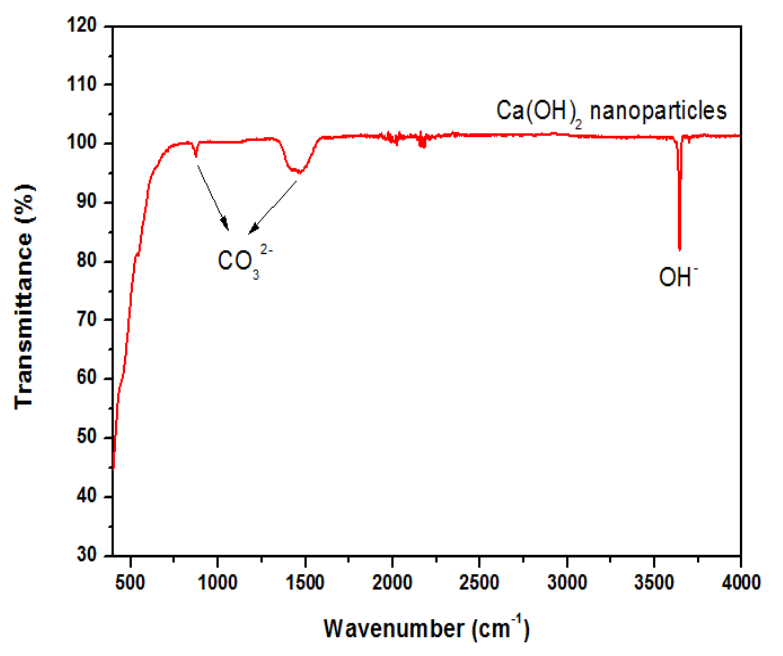

(b)

Figure 3. The FTIR patterns of (a) raw lime mud and (b) $\mathrm{Ca}(\mathrm{OH})_{2}$ nanoparticles.

\subsection{Phosphorus Treatment Application}

The effect of contact time on removal of phosphorus was investigated. The experimental data were collected within $60 \mathrm{~min}$ to reach chemical equilibrium in the solution. The initial phosphorus concentration was fixed at $15 \mathrm{mg} \mathrm{L}^{-1}$. The phosphorus removal efficiency of green calcium hydroxide versus contact time is presented in Figure 4. Initially, within $10 \mathrm{~min}$, the phosphorus removal rate increased rapidly and then reduced gradually until equilibrium was attained. The highest removal efficiency of phosphorus was obtained within $20 \mathrm{~min}$, as the system approaches equilibrium. The adsorption rate was rapid within the initial $10 \mathrm{~min}$ due to the presence of active sites on the surface of CNPs. However, due to continuous adsorption, those vacant sites started obtaining a saturation state, leading to limited contact between the phosphorus ions and surface area of the absorbent. Therefore, the phosphorus removal rate was lowered. The reaction reached chemical equilibrium when the surface of the CNPs was fully filled out by the phosphorus ions [43]. 


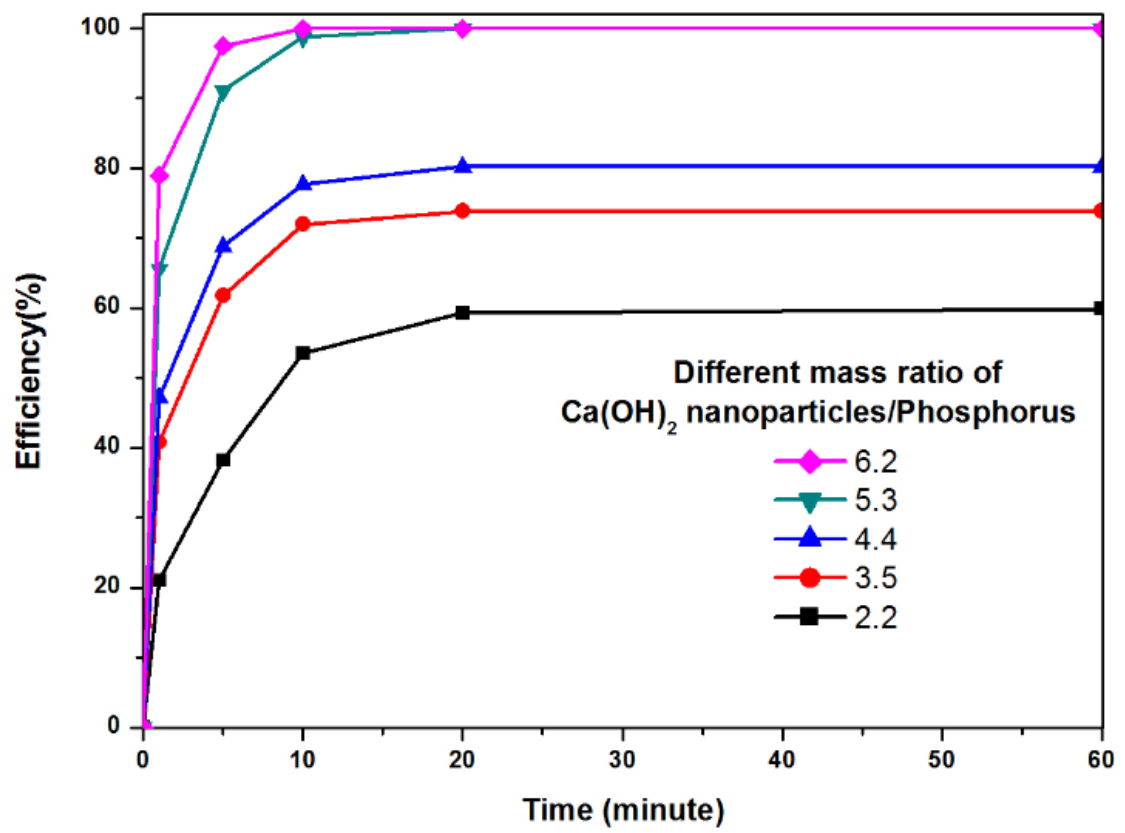

Figure 4. Effect of reaction time on phosphorus removal efficiency.

Figure 5 shows the effect of $\mathrm{Ca}(\mathrm{OH})_{2} \mathrm{NP}$ dosage on phosphorus removal within $10 \mathrm{~min}$. The results show that the efficiency of phosphorus removal increased with the increased mass ratio of adsorbent green calcium hydroxide nanoparticles/phosphorus due to more vacant sites and surface area of the adsorbent particles for adsorbing phosphorus ions. When the mass ratio of CNPs/P was increased from 2.2 to 6.2 , the phosphorus removal efficiency also increased from $53.5 \%$ to $100 \%$ within $10 \mathrm{~min}$.

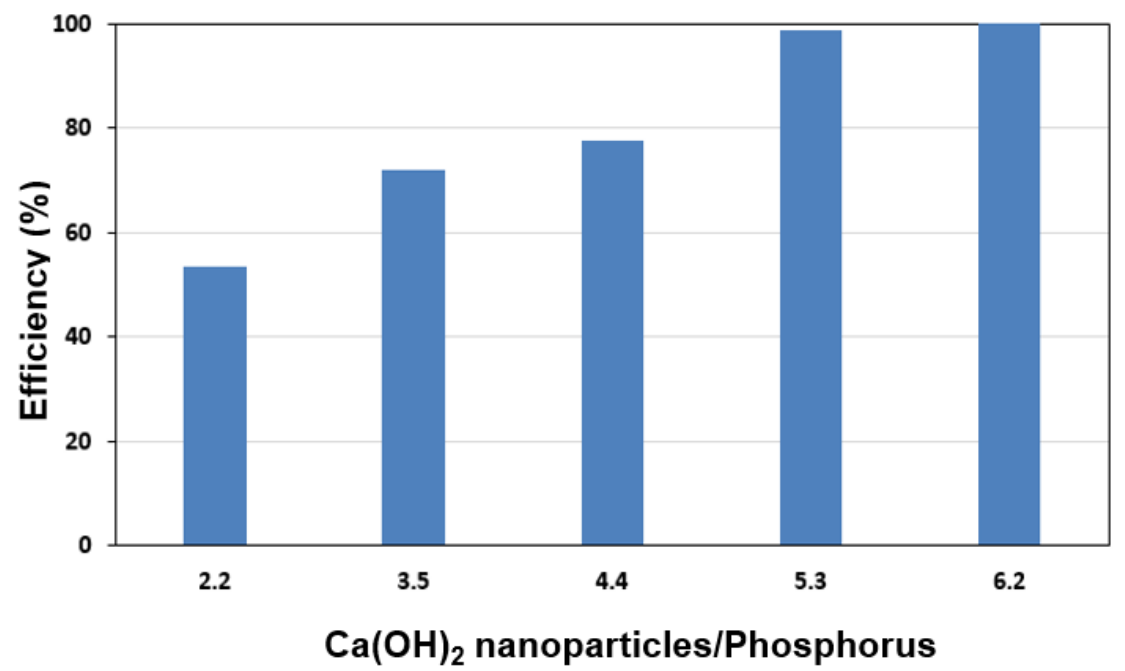

Figure 5. Effect of $\mathrm{Ca}(\mathrm{OH})_{2}$ dosage (mass ratio) on phosphorus removal within $10 \mathrm{~min}$.

Figure 6 illustrates the effect of absorbent dosage on removal of phosphorus with different contact time. The results indicated that the percent of phosphate adsorption increased when the mass ratio of CNPs/P and contact time were increased. When the mass ratio of CNPs/P were 2.2, 3.5, 4.4, 5.3, and 6.2 , the phosphorus removal efficiencies were $59.2 \%, 73.8 \%, 80.2 \%, 100 \%$, and $100 \%$, respectively $(t=20 \mathrm{~min})$. Other previous studies have also confirmed the enhancement of phosphorus removal efficiency with increasing adsorbent dosage and contact time. Torit et al. reported $80 \%$ phosphorus removal from domestic wastewater within $2 \mathrm{~h}$ with $5 \mathrm{~g}$ of calcinated eggshell in $1.7 \mathrm{mg} \mathrm{L}^{-1}$ of primary phosphorus concentration, which means the mass ratio of eggshell ash/phosphorus was 
about 2941 [43]. Deng et al. introduced a mass ratio of recycled concrete aggregate/phosphorus of 100, and about $95 \%$ phosphorus removal efficiency with $24 \mathrm{~h}$ contact time was achieved [44]. Nawar et al. determined that the removal efficiency of phosphorus ions from drinking water was $97 \%$ with a mass ratio of absorbent doses, alum sludge/phosphorus, of 50 within $30 \mathrm{~min}$ [45]. In this study, we reported $100 \%$ phosphorus removal efficiency with a mass ratio of CNPs/P of only 6.2 within $10 \mathrm{~min}$.

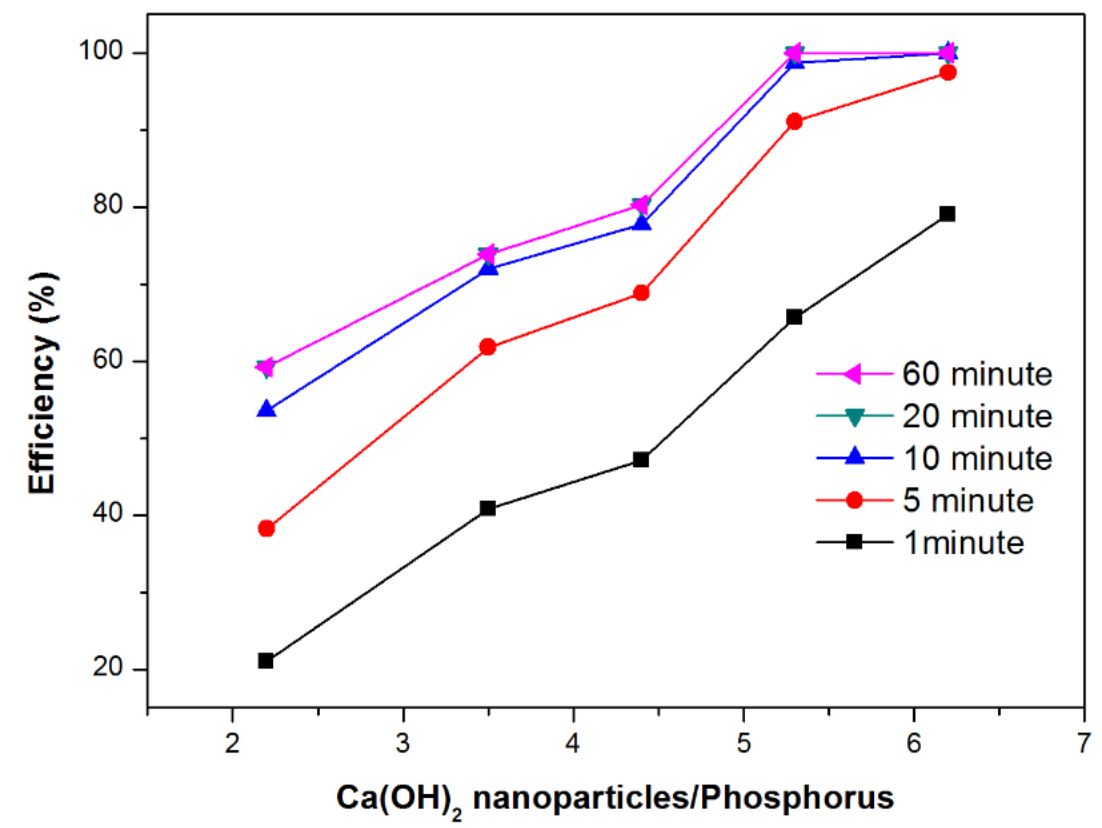

Figure 6. Effect of $\mathrm{Ca}(\mathrm{OH})_{2}$ dosage on removal of phosphorus with different contact time.

Figure 7 presents the phosphorus adsorption rate and shows that phosphorus removal capacity increased until chemical equilibrium. The graph shows that the best effective adsorption capacity was achieved at a mass ratio of 6.2 of $\mathrm{Ca}(\mathrm{OH})_{2}$ nanoparticles/phosphorus. The adsorption rate reached the maximum (adsorption capacity at equilibrium $=160.7 \mathrm{mg} / \mathrm{g}$, efficiency $=100 \%$ ) within $10 \mathrm{~min}$.

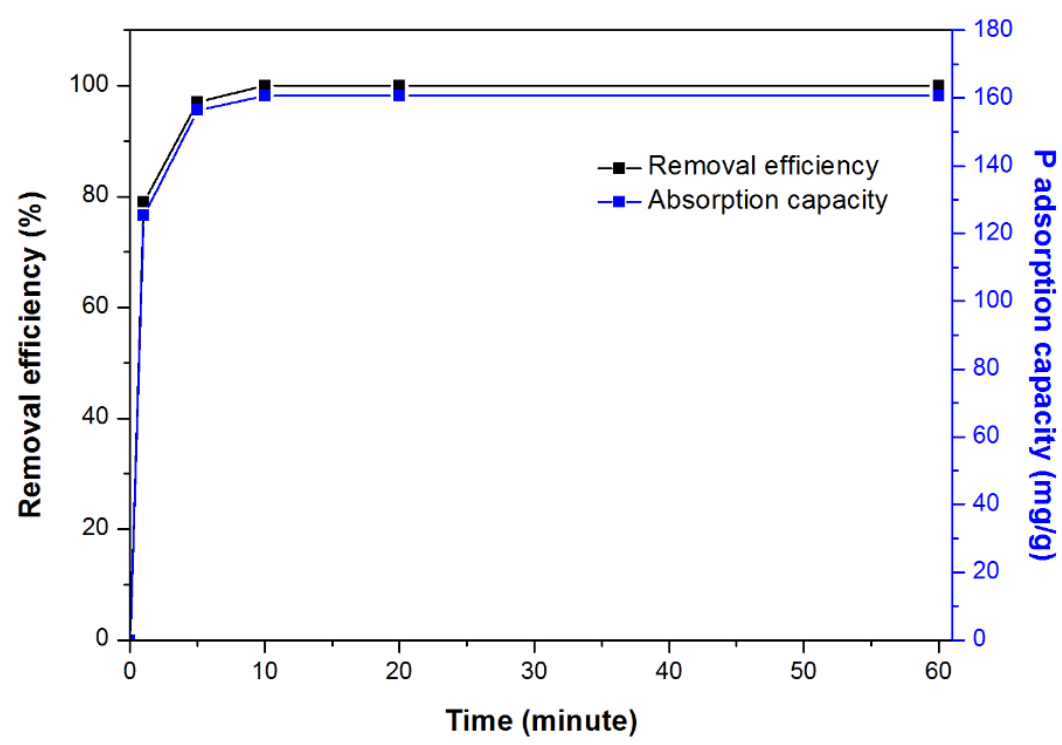

Figure 7. Kinetic studies of phosphorus adsorption. 


\section{Conclusions}

In this work, green hexagonal portlandite NPs were successfully synthesized from waste lime mud by a precipitation method. The crystal structure and hexagonal shape of calcium hydroxide nanoparticles were determined through XRD and FESEM. The average particle size was found to be about $550-700 \mathrm{~nm}$. In addition, the prepared $\mathrm{Ca}(\mathrm{OH})_{2}$ nanoparticles were introduced as an absorbent able to remove phosphorus. A perfect phosphorus removal efficiency of $100 \%$ was achieved within $10 \mathrm{~min}$ when a CNPs/P mass ratio of 6.2 was employed to remove phosphorus in $150 \mathrm{~mL}$ of $15 \mathrm{mg} \mathrm{L}^{-1}$ phosphorus solution. Due to the efficient phosphorus removal results, the nano-portlandite (CNPs) is strongly suggested as an appropriate absorbent in phosphorus treatment from domestic and industrial wastewater. Moreover, green portlandite production from lime mud has tremendous environmental and economic benefits with reduced residue storage.

Author Contributions: H.H.T.V., M.D.K., and R.C. planned and designed the experiment; H.H.T.V., T.Q.L., and C.R. carried out the experiments; H.H.T.V. and M.D.K. analyzed the data and wrote the paper; T.T., D.U.P., J.W.A., and J.K. reviewed and revised the manuscript.

Funding: This research was supported by the National Strategic Project-Carbon Mineralization Flagship Center of the National Research Foundation of Korea (NRF) funded by the Ministry of Science and ICT (MSIT), the Ministry of Environment (ME), and the Ministry of Trade, Industry, and Energy (MOTIE) (2017M3D8A2084752).

Conflicts of Interest: The authors declare no conflict of interest.

\section{References}

1. He, J.J.; Lange, C.R.; Dougherty, M. Laboratory study using paper mill lime mud for agronomic benefit. Process Saf. Environ. 2009, 87, 401-405. [CrossRef]

2. Nurmesniemi, H.; Poykio, R.; Keiski, R.L. A case study of waste management at the Northern Finnish pulp and paper mill complex of Stora Enso Veitsiluoto Mills. Waste Manag. 2007, 27, 1939-1948. [CrossRef] [PubMed]

3. Zhou, Y.T.; Zhao, H.; Bai, H.L.; Zhang, L.P.; Tang, H.W. Papermaking effluent treatment: A new cellulose nanocrystalline/polysulfone composite membrane. Proc. Environ. Sci. 2012, 16, 145-151. [CrossRef]

4. Paper Industry-Statistics \& Facts. Available online: https://www.statista.com/topics/1701/paperindustry/ (accessed on 30 January 2019).

5. Production Volume of Paper and Cardboard in Major Countries from 2009 to 2016 (in 1000 Metric Tons). Available online: https://www.statista.com/statistics/240598/production-of-paper-and-cardboard-inselected-countries / (accessed on 30 January 2019).

6. Wirojanagud, W.; Tantemsapya, N.; Tantriratna, P. Precipitation of heavy metals by lime mud waste of pulp and paper mill. Songklanakarin J. Sci. Technol. 2004, 26, 45-53.

7. Ren, X. Cleaner production in China's pulp and paper industry. J. Clean. Prod. 1998, 6, 349-355. [CrossRef]

8. Liu, Y.J.; Naidu, R.; Ming, H. Red mud as an amendment for pollutants in solid and liquid phases. Geoderma 2011, 163, 1-12. [CrossRef]

9. Monte, M.C.; Fuente, E.; Blanco, A.; Negro, C. Waste management from pulp and paper production in the European Union. Waste Manag. 2009, 29, 293-308. [CrossRef]

10. Madrid, M.; Orbe, A.; Carre, H.; Garcia, Y. Thermal performance of sawdust and lime-mud concrete masonry units. Constr. Build. Mater. 2018, 169, 113-123. [CrossRef]

11. Hartley, W.; Edwards, R.; Lepp, N.W. Arsenic and heavy metal mobility in iron oxide-amended contaminated soils as evaluated by short- and long-term leaching tests. Environ. Pollut. 2004, 131, 495-504. [CrossRef]

12. Bellaloui, A.; Chtaini, A.; Ballivy, G.; Narasiah, S. Laboratory investigation of the control of acid mine drainage using alkaline paper mill waste. Water Air Soil Pollut. 1999, 11, 57-73. [CrossRef]

13. Correa, T.H.A.; Toledo, R.; Silva, N.S.; Holanda, J.N.F. Novel nano-sized biphasic calcium phosphate bioceramics ( $\beta-\mathrm{CPP} / \beta-\mathrm{TCP})$ derived of lime mud waste. Mater. Lett. 2019, 243, 17-20. [CrossRef]

14. Zhang, J.; Zheng, P.; Wang, Q. Lime mud from papermaking process as a potential ameliorant for pollutants at ambient conditions: A review. J. Clean. Prod. 2015, 103, 828-836. [CrossRef]

15. Qin, J.; Cui, C.; Cui, X.; Hussain, A.; Yang, C. Preparation and characterization of ceramite from lime mud and coal fly ash. Constr. Build. Mater. 2015, 95, 10-17. [CrossRef] 
16. Yang, X.; Wan, Y.; Zheng, Y.; He, F.; Yu, Z.; Huang, J.; Wang, H.; Ok, Y.S.; Jiang, Y.; Gao, B. Surface functional groups of carbon-based adsorbents and their roles in the removal of heavy metals from aqueous solutions: A critical review. Chem. Eng. J. 2019, 366, 608-621. [CrossRef]

17. Chaudhary, M.; Maiti, A. Defluoridation by highly efficient calcium hydroxide nanorods from synthetic and industrial wastewater. Colloids Surf. A. Physicochem. Eng. Asp. 2019, 561, 79-88. [CrossRef]

18. Hu, H.; Li, X.; Huang, P.; Zhang, Q.; Yuan, W. Efficient removal of copper from wastewater by using mechanically activated calcium carbonate. J. Envron. Manag. 2017, 203, 1-7. [CrossRef]

19. Krishna, K.C.B.; Niaz, M.R.; Sarkar, D.C.; Jansen, T. Phosphorus removal from aqueous solution can be enhanced through the calcination of lime sludge. J. Envron. Manag. 2017, 200, 359-365. [CrossRef]

20. Baraka, A.M.; El-Tayieb, M.M.; Shafai, M.E.; Mahamed, N.Y. Sorptive removal of phosphate from wastewater using activated red mud. Aust. J. Basic Appl. Sci. 2012, 6, 500-510.

21. Ni, F.; He, J.; Wang, Y.; Luan, Z. Preparation and characterization of a cost-effective red mud/polyaluminum chloride composite coagulant for enhanced phosphate removal from aqueous solutions. J. Water Process Eng. 2015, 6, 158-165. [CrossRef]

22. Kruger, O.; Adam, C. Phosphorus in recycling fertilizers-Analytical challenges. Environ. Res. 2017, 155, 353-358. [CrossRef]

23. Eussen, S.R.; Verhagen, H.; Klungel, O.H.; Garssen, J.; van Loveren, H.; van Kranen, H.J.; Rompelberg, C.J. Functional foods and dietary supplements: Products at the interface between pharma and nutrition. Eur. J. Pharmacol. 2011, 668, S2-S9. [CrossRef] [PubMed]

24. Puijenbroek, P.J.T.M.V.; Beusen, A.H.W.; Bouwman, A.F. Datasets of the phosphorus content in laundry and dishwasher detergents. Data Brief 2018, 21, 2284-2289. [CrossRef] [PubMed]

25. Ott, C.; Degg, A.; Walke, P.; Reiter, F.; Nilges, T. Influence of copper on the capacity of phosphorus-anode in sodium-ion-batteries. J. Solid State Chem. 2019, 270, 636-641. [CrossRef]

26. Harrison, R.M. Pollution: Causes, Effects, and Control, 3rd ed.; The Royal Society of Chemistry: London, UK, 1996.

27. Kiely, G. Environmental Engineering; McGrawHill: New York, NY, USA, 1997.

28. Hosni, K.; Ben, M.S.; Chachi, A.; Ben Amor, M. The removal of $\mathrm{PO}_{4}{ }^{3-}$ by calcium hydroxide from synthetic wastewater: Optimisation of the operating conditions. Desalination 2008, 223, 337-343. [CrossRef]

29. Yang, M.; Shi, J.; Xu, Z.; Zhu, S.; Cui, Y. Phosphorus removal and recovery from fosfomycin pharmaceutical wastewater by the induced crystallization process. J. Environ. Manag. 2019, 231, 207-212. [CrossRef]

30. Zhang, J.; Bligh, M.W.; Liang, P.; Waite, T.D.; Huang, X. Phosphorus removal by in situ generated Fe(II): Efficacy, kinetics and mechanism. Water Res. 2018, 136, 120-130. [CrossRef]

31. Namasivayam, C.; Sakoda, A.; Suzuki, M. Technical Note: Removal of phosphate by adsorption onto oyster shell powder-kinetic studies. J. Chem. Technol. Biotechnol. 2011, 80, 356-358. [CrossRef]

32. Xiong, J.; Quin, Y.; Islam, E.; Yue, M.; Wang, W. Phosphate removal from solution using powdered freshwater mussel shells. Desalination 2011, 276, 317-321. [CrossRef]

33. Penn, C.J.; Bryant, R.B.; Callahan, M.P.; McGrath, J.M. Use of Industrial By-products to Sorb and Retain Phosphorus. Commun. Soil Sci. Plant Anal. 2011, 42, 633-644. [CrossRef]

34. Khan, M.D.; Ahn, J.W.; Nam, G. Environmental benign synthesis, characterization and mechanism studies of green calcium hydroxide nano-plates derived from waste oyster shells. J Environ. Manag. 2018, 223, 947-951. [CrossRef]

35. Madrid, J.A.; Lanzon, M. Synthesis and morphological examination of high-purity $\mathrm{Ca}(\mathrm{OH})_{2}$ nanoparticles suitable to consolidate porous surfaces. Appl. Surf. Sci. 2017, 424, 2-8. [CrossRef]

36. Bindu, P.; Thomas, S. Estimation of lattice strain in $\mathrm{ZnO}$ nanoparticles: X-ray peak profile analysis. J. Theor. Appl. Phys. 2014, 8, 123-134. [CrossRef]

37. Venkateswarlu, K.; Sandhyarani, M.; Nellaippan, T.A.; Rameshbabu, N. Estimation of crystallite size, lattice strain and dislocation density of nanocrystalline carbonate substituted hydroxyapatite by V-ray peak variance analysis. Proc. Mater. Sci. 2014, 5, 212-221. [CrossRef]

38. Shafi, P.M.; Bose, A.C. Impact of crystalline defects and size on X-ray line broadening: A phenomenological approach for tetragonal $\mathrm{SnO}_{2}$ nanocrystals. AIP Adv. 2015, 5, 057137. [CrossRef]

39. Darroudi, M.; Bagherpour, M.; Hosseini, H.A.; Ebrahimi, M. Biopolymer-assisted green synthesis and characterization of calcium hydroxide nanoparticles. Ceram. Int. 2016, 42, 3816-3819. [CrossRef] 
40. Pereira, M.R.N.; Salviano, A.B.; Medeiros, T.P.; Santos, M.R.D.; Cibaka, T.E.; Andrade, M.H.C.; Porto, A.O.; Lago, R.M. $\mathrm{Ca}(\mathrm{OH})_{2}$ nanoplates support on activated carbon for the neutralization/removal of free fatty acids during biodiesel production. Fuel 2018, 221, 469-475. [CrossRef]

41. Makreski, P.; Jovanovski, G. Minerals from Macedonia IX. Distinction between some rhombohedral carbonates by FT IR spectroscopy. Bull. Chem. Technol. Macedonia 2003, 22, 25-32.

42. Asikin-Mijan, N.; Taufiq-Yap, Y.H.; Lee, H.V. Synthesis of clamshell derived $\mathrm{Ca}(\mathrm{OH})_{2}$ nano-particles via simple surfactant-hydration treatment. Chem. Eng. J. 2015, 262, 1043-1051. [CrossRef]

43. Torit, J.; Phihusut, D. Phosphorus removal from waste water using eggshell ash. Environ. Sci. Pollut. Res. Int. 2018, 25, 1-9.

44. Deng, Y.; Wheatley, A. Mechanisms of phosphorus removal by recycled crushed concrete. Int. J. Environ. Res. Public Health 2018, 15, 357. [CrossRef]

45. Nawar, N.; Ahmad, M.E.; El Said, W.M.; Moalla, S.M.N. Adsorptive removal of phosphorus from wastewater using drinking water treatment-alum sludge (DWT-AS) as low cost adsorbent. Am. J. Chem. Appl. 2015, 2, $79-85$.

(C) 2019 by the authors. Licensee MDPI, Basel, Switzerland. This article is an open access article distributed under the terms and conditions of the Creative Commons Attribution (CC BY) license (http://creativecommons.org/licenses/by/4.0/). 